\title{
STRUCTURAL DIVERSITY OF DEAD WOOD IN SMALL-SCALED PROTECTED FOREST PARCELS IN LATVIA
}

\author{
Līga Liepa ${ }^{1}$, Inga Straupe ${ }^{1}$, Olga Miezīte ${ }^{1}$, Āris Jansons ${ }^{2}$ \\ ${ }^{1}$ Latvia University of Life Sciences and Technologies, Latvia \\ ${ }^{2}$ Latvian State Forest Research Institute 'Silava', Latvia \\ liga.liepa@llu.lv
}

\begin{abstract}
Dead wood is a significant component in forested ecosystems. In Fennoscandia and Baltic countries, set-aside forest areas, also called woodland key habitats (WKHs), have been created for nature conservation purposes in the production forest landscape. We performed a comparative study on dead wood substrate availability in different WKH types in Latvia. We measured standing trunks and downed logs to estimate biological quantities and qualities for coarse woody debris substrate. In this study, we found out that dead wood availability ranges, on average, from 38.2 to $149.5 \mathrm{~m}^{3} \mathrm{ha}^{-1}$. This study showed that moderate quantity and quality of dead wood has been found in different types, but the fine quality coarse woody debris was scarcely presented. In general, WKHs provide moderate and high level of qualities and quantities of structural features in the production forest landscape.
\end{abstract}

Key words: disturbance dynamics, tree mortality, woodland key habitats, coarse woody debris, diversity of the dead wood.

\section{Introduction}

Achieving an optimal amount of coarse woody debris is essential for species depending on this substrate in forested ecosystems. The lack of dead wood substrate is particularly common in production forests. To fulfill the forest certification requirements and to reach the nature conservation targets outside the protected areas, a network of small-scale conservation areas at the forest stand level were established in the Baltic and Fennoscandian production forests. These small scale set-asides, also called woodland key habitats, have their average size from 0.7 ha in Southern Finland, 2.5 ha in Latvia to 4.6 ha in Sweden (Timonen et al., 2011), have been intact from management and function as hotspots for biodiversity purposes since 1990s (Anon, 2005). To select the forest parcels with a high value for biodiversity qualities, the vast stand-level survey was made in the production forest landscape, which included the criteria for stand structural features (e.g., mature or over-mature stand age, dead wood qualities), presence of indicator species, rare and threatened species, cultural heritage value and others. Most of the conservation targets in these small forest parcels are related to dynamic ecosystem processes, e.g., natural disturbances and succession, and biodiversity qualities, for example, presence of dead wood and large dimension trees, as well as, rare and threatened species (e.g. fungi, lichens, bryophytes, saproxylic species and vascular plants). Multiple studies on many organism groups have tested whether such a small-scale conservation approach is cost-efficient and provides expected outcomes. For instance, in an investigation into boreal forest ecosystems, Gustafsson (2000) and Perhans (2007) detected the occurrence of rare and threated bryophytes, lichens and vascular plants. However, the study on the edge influence on epiphytic lichens in boreo-nemoral swamp forests reports that the occurrence of rare species is higher at the distance of $40-50 \mathrm{~m}$ compared to $10-20 \mathrm{~m}$ and $20-30 \mathrm{~m}$ from the habitat's edge (Liepa \& Straupe, 2015). Other studies have stated that small forest parcels are lacking habitat qualities due to their small size, isolation, influence of the edge effect, and lack of the core area due to their small size (e.g., Aune et al., 2005; Timonen et al., 2011; Liepa, 2017). Furthermore, these small forest parcels are characterized as 'edge habitats' where diverse dead wood substrate is available, because sites are more affected by changes in abiotic condition and, therefore, desiccation, wind, wildfire or other agents may cause the death of living trees.

In recent years, the awareness of the importance of dead wood in forest ecosystems has been widely discussed. It is known that dead wood provides important resources for a wide range of organisms, which directly and indirectly depend on this substrate. Besides this, dead wood also contributes to carbon sequestration (Ķeninina et al., 2018), nutrient cycles, enhancement of natural regeneration, as well as essentially provides substrate for many rare and endangered species. In particular, in Latvia 94 rare and threatened species both indirectly -25 and directly 69 are dependent on dead wood substrate (Cabinet of Ministers, No. 396). In boreal forest landscape, the occurrence of approximately 7000 species is linked to the above-mentioned characteristics (Stokland et al., 2012).

In general, dead wood is characterized as a dynamic substrate that can develop over time. Some studies have recorded the importance of dead wood continuity, because in each decay stage different taxa have been detected. Overall, the diversity of dead wood is characterized by tree species, diameter, length, decay stage and spatial distribution. The current dead 
wood availability amount and critical values of dead wood substrate have been assessed in recent studies. For instance, in Sweden's production forest landscape the average amount of coarse woody debris is 6.1 $\mathrm{m}^{3}$ per ha, in Finland $-5.4 \mathrm{~m}^{3}$ per ha (Fridamn \& Walheim, 2000), but the critical values for species in this biome vary from $15-20 \mathrm{~m}^{3}$ per ha. Furthermore, in temperate forest ecosystems the values of thresholds range from 20 to $30 \mathrm{~m}^{3}$ per ha (Muller \& Butler, 2010). These values may be higher than general volume of dead wood found in the production forest landscape. Therefore, such small-scale protected forest parcels might favorably function as 'lifeboats' for species demanding dead wood substrate in the production forest landscape. In this study, we investigated the availability of dead wood substrate in different forest types. To evaluate whether protected small-scaled forest parcels provide high biodiversity qualities and continuity of dead wood substrate, we have described decay stage distribution, different sizes and currently available volume.

\section{Materials and Methods}

Forests of Latvia are located in boreo-nemoral biome (Sjörs, 1963), which combines the elements from both boreal and nemoral forests. This study was conducted in 45 forest stands in southern Latvia (Figure 1), which represent Zemgale geobotanical region.

These plots fall into Zemgale plain, are dominated by agriculture and have fertile, naturally well-drained soils. In contrast to Latvia in general, where the forest proportion is $52 \%$ (Mežu statistiskā inventrizācija, 2014), forested areas occupy approximately $20 \%$ of region's area, mostly in small patches. Historical analysis shows that forests have been much more common in this area a few centuries ago, mostly broadleaved forests (Angelstam et al., 2005; Galeniece, 1959). The most common tree species include Scots pine Pinus sylvestris L., silver birch Betula pendula
Roth. and downy birch Betula pubescens Ehrh., Norway spruce Picea abies (L.) H. Karst., black alder Alnus glutinosa (L.) Gaertn., grey alder Alnus incana (L.) Moench., common aspen Populus tremula L., and broad-leaved species at their northern limit of the distribution. The climate ranges from transitional maritime to continental toward the eastern part of the country. The average temperature in February is $-3.6{ }^{\circ} \mathrm{C}$ and $16.9{ }^{\circ} \mathrm{C}$ in July. Average yearly precipitation is approximately $709 \mathrm{~mm}$.

In Zemgale, forests are managed predominantly for timber production and only small forest parcels are excluded from silvicultural practices. Study plots are located in state-owned forests and all stands have the status of protected habitats since 1990s as woodland key habitats (WKH, sensu Timonen et al., 2010) voluntarily set-aside forest stands. The complete inventory of natural values and biodiversity qualities is currently being carried out in Latvia and many of these woodland key habitats are properly transformed as European Union protected habitats (Evans, 2006). The manuals for criteria are mainly based on the presence of indicator species, rare and threatened species, and diversity of stand structural features. Study sites represented black alder WKHs with age $\geq 81$ years, which are designated as an EU protected habitat type: Fennoscandian deciduous swamp forests (further - swamp forests), boreal Scots pine stands with age $\geq 120$ years (further - coniferous forests), and nemoral broad-leaved stands dominated by common ash (Fraxinus excelsior L.) and Penducalate oak (Quercus robur) with age $\geq 120$ years (further - broadleaved forests). All studied stands were semi-natural, located in close proximity to each other and had been managed in a similar manner. The evident influence of silvicultural practices of forests within existing WKHs likely consisted of thinning and forest drainage; few of them are located nearby forest roads.

Data collection. A string of permanent sample plots was established in each study site from the stand edge
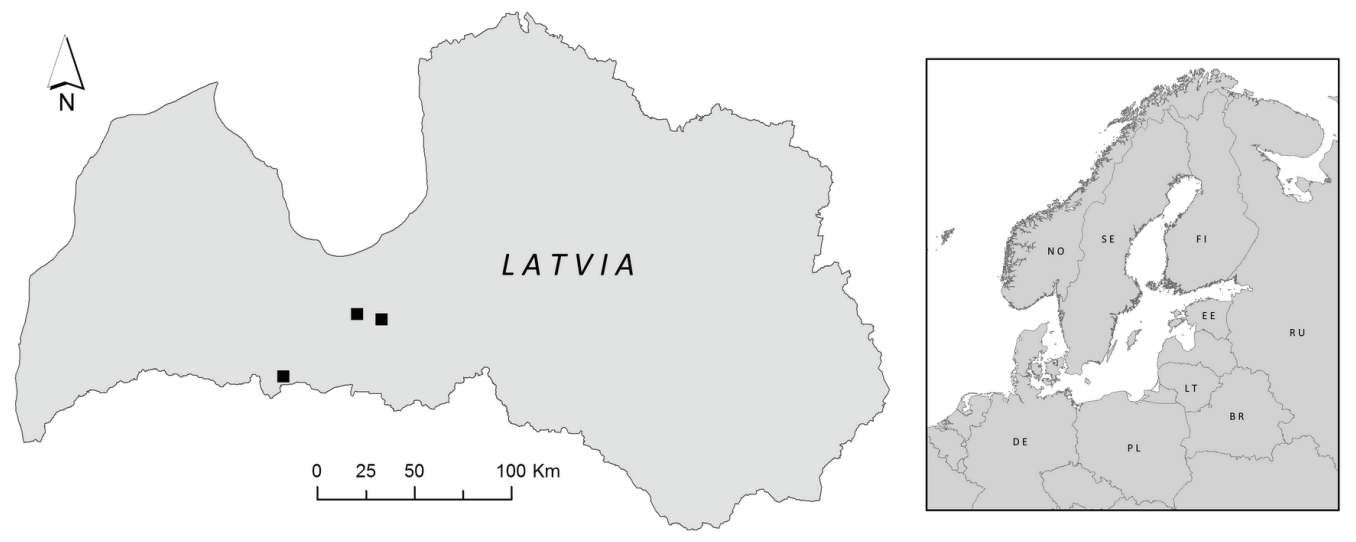

Figure 1. The location of study sites. 
into forest interior (from S or SW side) to describe the gradient. The size of sample plots was $20 \times 50 \mathrm{~m}$. Plots represented forest edges with $\mathrm{S}$ or $\mathrm{S}-\mathrm{W}$ exposition.

Stand structural features. Inside sample plots coarse woody debris (CWD) was measured by diving it into categories: standing dead trees and downed dead $\operatorname{logs}$, and their items (diameter $\geq 10 \mathrm{~cm}$ and minimum length $\geq 1 \mathrm{~m}$ ). Tree species for those were determined whenever it was possible. Downed dead wood and their items were recorded at intersection with sample plot. In addition, downed dead wood items, such as branches anddowned shrubs were included as well as all remaining CWD under water, specifically, in swamp forests. The decay stage classification was from one to five following Stokland (2001). The volumes of CWD were computed using the volume formulas presented by Liepa (1996).

\section{Results and Discussion}

The highest average volume of dead wood quantities found in this study was $149.5 \mathrm{~m}^{3} \mathrm{ha}^{-1}$ in broad-leaved forest parcels. A high amount of dead wood was also found in swamp forest sites $48 \mathrm{~m}^{3} \mathrm{ha}^{-1}$ (Figure 2). Standing dead wood made up $72 \%$ in swamp forest parcels, followed by $38 \%$ in coniferous stands and only $12 \%$ in broad-leaved forests. Following from the main cause of mortality, clear differences were found in broad-leaved forest stands, which are currently affected by ash dieback, particularly, in southern part of Latvia (Broka et al., 2017; Matisone et al., 2018). Historically, this region was dominated by Penduculate oak, common ash and small-leaved lime (Tilia cordata Mill.), however, only $4 \%$ of forests are associated with nemoral broadleaved habitats (Fescenko, 2014). In contrast, natural gap dynamic processes are characterized by swamp forests, because large quantities of dead wood are standing snags and stems (Figure 2).

Multiple studies have revised quantities of dead wood in old-growth forest stands and in boreal and temperate European forest landscapes, where the average volume of dead wood is ranging from 8 to $141 \mathrm{~m}^{3} \mathrm{ha}^{-1}$ (Moning \& Müller, 2008; Stokland et al., 2012). However, the equilibrium between the occurrence of standing dead wood and fallen logs is commonly suggested. According to the above mentioned, the proportion of standing and downed dead wood (49.5\% and 50.5\%, respectively) in the studied coniferous forest stands is fairly similar.

To classify the quantities of dead wood, also diameter distribution classes are commonly investigated. The diameter distribution of standing snags and stems showed a pattern where the highest proportion consists of small diameter classes in all studied sites (Figure 3 ). The highest proportion of medium-diameter classes (from $20.0-29.9 \mathrm{~cm}$ at the $\mathrm{DBH}$ ) was recorded in coniferous forest parcels - on average $49.2 \%$. The large dimension classes represent $20.3 \%$ in coniferous stands, followed by broad-leaved stands $-14.3 \%$ and swamp forests $-8.2 \%$.

In general, few studies have reported the proportion of standing trees in different trunk diameter classes (Nilsson et al., 2003; Siitonen et al., 2000). Generally, the competitive exclusion is the main driver, which induces the mortality of small dimension trees.

It is known that many forest-dwelling species are related to the large-dimension dead wood substrate and, therefore, nature conservation is aiming at these quantities.

However, taking whole coarse woody debris substrate into account, the earlier decay stages 1 and 2 were most abundant in terms of occurrence, volume and

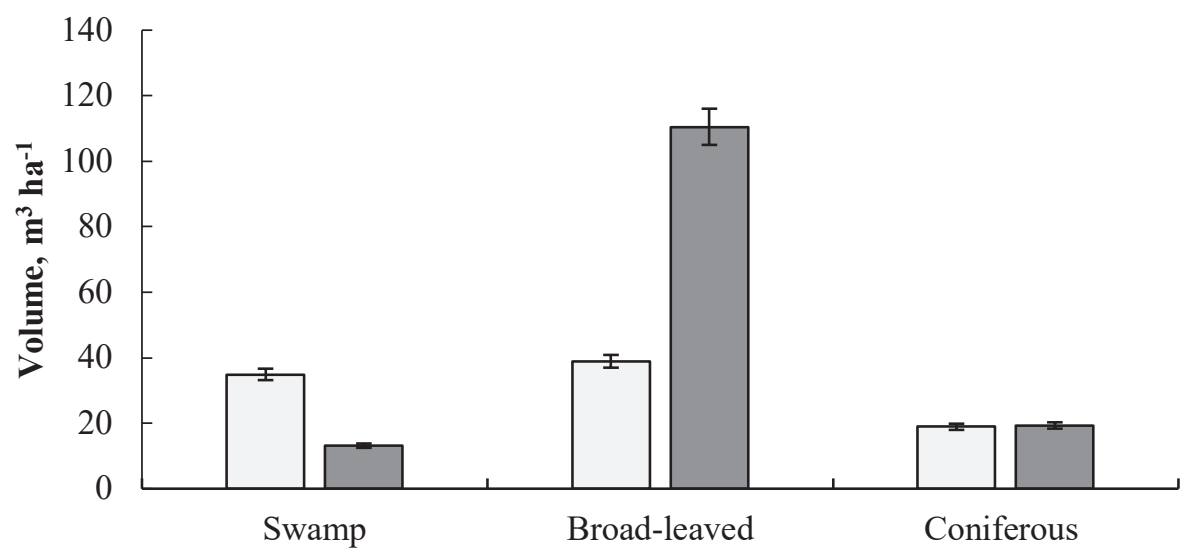

Forest types

$\square$ Standing CWD $\square$ Downed CWD

Figure 2. The average volume of standing and downed coarse woody debris in different habitat types: swamp, broad-leaved and coniferous. Error bars represent standard errors. 


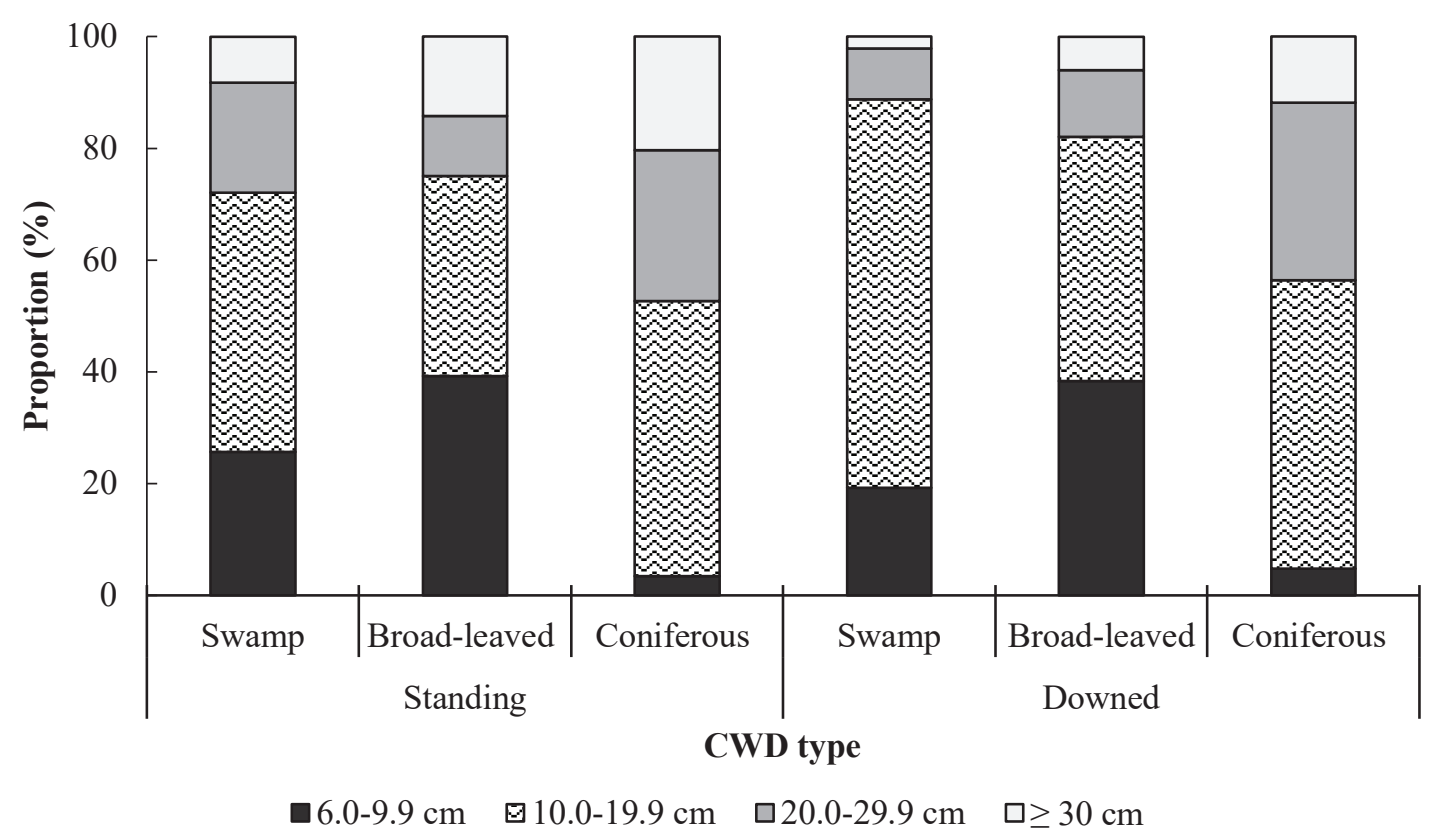

Figure 3. The proportion of coarse woody debris by diameter distribution in different habitat types: swamp, deciduous and coniferous habitats.

density (Figure 4). Decay stage 1 (recently dead trees with remaining bark and solid structure) comprised $87 \%$ in swamp forests, followed by broad-leaved and coniferous forests ( $54 \%$ and $42 \%$, respectively). Only a small proportion of moderate decay stages are present in the studied areas, for instance, in broadleaved forests $-9.4 \%$ and in coniferous $-15.3 \%$, but in the swamp forests they were not found.

It is important to understand the decay dynamics of dead wood substrate to predict the substrate continuity in longer term. According to the studies, the decomposition of Norway spruce and Scots pine may take some decades, or even longer under constant climatic environments (Stokland, 2001). By contrast, it takes between 10 to 20 years for deciduous trees to reach the most decomposed decay class. The presence of many taxa from epixylic species, vertebrates, invertebrates, reptiles and amphibians to mammals strongly correlates with substrate decomposition rate. However, the decay stage, dimensions, spatial distribution, and biotic interaction, which can differ among diversity of woody plant species, biomes, and

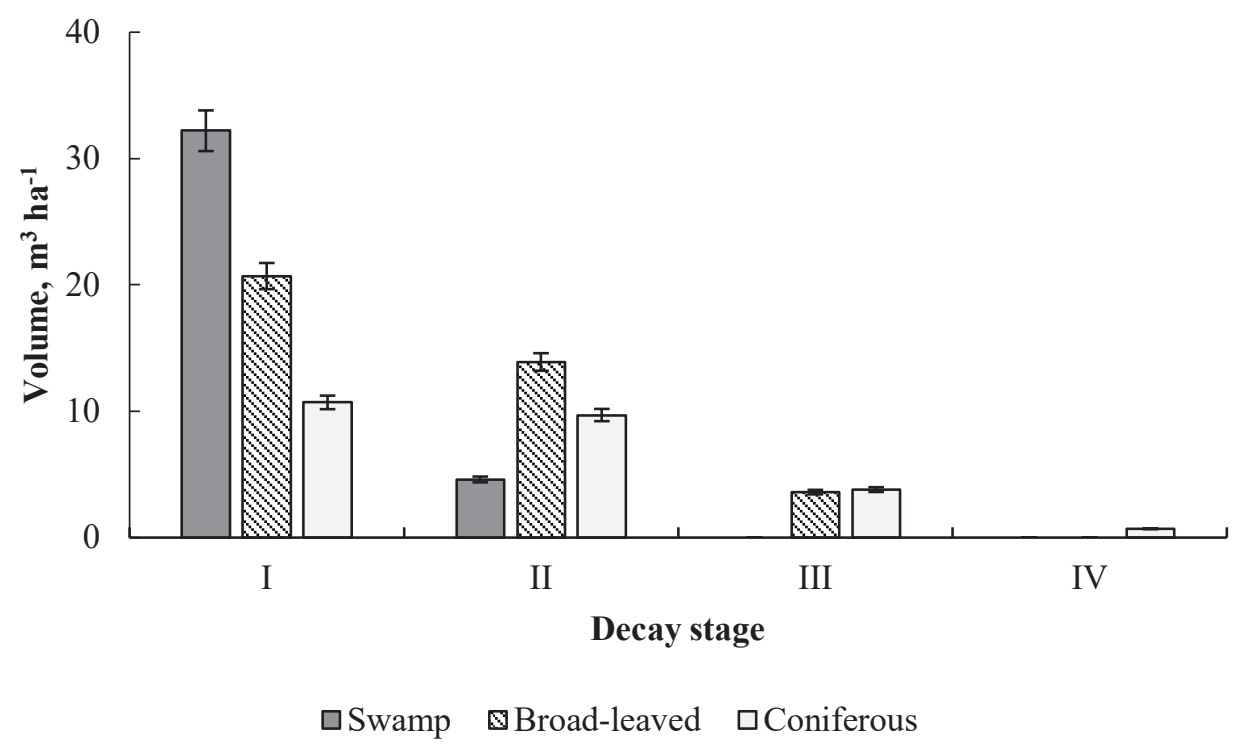

Figure 4. The volume of coarse woody debris by different decay stages in various habitat types: swamp, broad-leaved and coniferous habitats. Error bars represent standard errors. 
landscapes, eventually characterize the dynamics of quality change and dead wood continuity in the forest ecosystems. In order to investigate long-term dynamics on dead wood quantities, common simulation models were used in the previous studies.

\section{Conclusions}

This study showed that moderate quantity and quality of dead wood has been found in different types of protected habitats in the production forest landscape. Results from this study also support the hypothesis that dead wood substrate occurs in fairly large quantities. In general, the total amount of dead wood, including snags, stems and logs are consistently available in small forest parcels for providing biodiversity qualities. The largest amount of substrate availability was particularly detected at the early decay stages. This might be correlated with human-induced disturbances in the adjacent forest matrix. However, the lack of available substrate and dynamic environmental conditions may have negatively affected the species with strong habitat requirements for stable microclimatic conditions. In addition, deeper investigation is needed to understand the spatial distribution patterns and to determine strict numbers for thresholds and compared dead wood quantities with managed stands in different age classes.

\section{Acknowledgements}

This study was financially supported by the ERDF Post-doctoral Research Support Program (project No.1.1.1.2/16/I/001) Research application 'Balancing ecological interests with increasing demands for natural resources in production forests.' (No. 1.1.1.2./ VIAA/2/18/294).

\section{References}

1. Anon. (2005). Management of woodland key habitats in Latvia. Final report Riga State Forest Service, Joint Stock Company \& Regional Forestry Board of Östra Götaland

2. Aune, K., Jonsson, B.G., \& Moen, J. (2005). Isolation and edge effects among woodland key habitats in Sweden: is forest policy promoting fragmentation? Biological Conservation, 124(1), 89-95. DOI: 10.1016/j.biocon.2005.01.015.

3. Broka, D., Liepa, L., \& Straupe, I. (2017). The assessment of vegetation in unmanaged nemoral forests in Zemgale [Latvia]. In Research for Rural Development. International Scientific Conference Proceedings (Latvia), 17-19 May 2017 (pp. 41-46). Jelgava, Latvia, Latvia University of Agriculture. DOI: 10.22616/ rrd.23.2017.006.

4. Cabinet of Ministers No. 396. Retrieved January 18, 2019, from https://likumi.lv/ta/en/en/id/12821.

5. Evans, D. (2006). The habitats of the European Union habitats directive. Biology and Environment: Proceedings of the Royal Irish Academy, 167-173.

6. Fescenko, A., Nikodemus, O., \& Brūmelis, G. (2014). Past and contemporary changes in forest cover and forest continuity in relation to soils (Southern Latvia). Polish Journal of Ecology, 62(4), 625-639. DOI: 10.3161/104.062.0408.

7. Fridman, J., \& Walheim, M. (2000). Amount, structure, and dynamics of dead wood on managed forestland in Sweden. Forest Ecology and Management, 131(1-3), 23-36. DOI: 10.1016/S0378-1127(99)00208-X.

8. Gustafsson, L. (2000). Red-listed species and indicators: vascular plants in woodland key habitats and surrounding production forests in Sweden. Biological Conservation, 92(1), 35-43. DOI: 10.1016/S00063207(99)00064-6.

9. Ķēniņa, L., Elferts, D., Bāders, E., \& Jansons, Ā. (2018). Carbon Pools in a Hemiboreal Over-Mature Norway spruce Stands. Forests, 9(7), 435-445. DOI: 10.3390/f9070435.

10. Liepa, I. (1996). Pieauguma mācība (Increment science). Jelgava: Latvia University of Agriculture. (in Latvian)

11. Liepa, L., \& Straupe, I. (2015). Edge effects on epiphytic lichens in unmanaged black alder stands in southern Latvia. In Annual $21^{\text {st }}$ International Scientific Conference Research for Rural Development Vol. 2, Jelgava, Latvia, 13-15 May 2015 (pp. 44-49). Jelgava, Latvia, Latvia University of Agriculture.

12. Liepa, L. (2017). The influence of edge effects on vegetation in black alder forests in Zemgale [Latvia]. Summary of the doctoral thesis, Latvia University of Agriculture, Jelgava, Latvia. DOI: 10.22616/ LLUthesis/2017.013.

13. Matisone, I., Matisons, R., Laivins, M., \& Gaitnieks, T. (2018). Statistics of ash dieback in Latvia. Silva Fennica, 52, 1-6. DOI: 10.14214/sf.990.

14. Moning, C., \& Müller, J. (2008). Environmental key factors and their thresholds for the avifauna of temperate montane forests. Forest Ecology and Management, 256(5), 1198-1208. DOI: 10.1016/j. foreco.2008.06.018. 
15. Nilsson, S.G., Niklasson, M., Hedin, J., Aronsson, G., Gutowski, J.M., Linder, P., Ljungberg, H., Mikusiński, G., \& Ranius, T. (2003). Erratum to 'Densities of large living and dead trees in old-growth temperate and boreal forests'. Forest Ecology and Management, 178(3), 355-370. DOI: 10.1016/S03781127(03)00084-7.

16. Perhans, K., Gustafsson, L., Jonsson, F., Nordin, U., \& Weibull, H. (2007). Bryophytes and lichens in different types of forest set-asides in boreal Sweden. Forest Ecology and Management, 242(2-3), 374390. DOI: 10.1016/j.foreco.2007.01.055.

17. Siitonen, J., Martikainen, P., Punttila, P., \& Rauh, J. (2000). Coarse woody debris and stand characteristics in mature managed and old-growth boreal mesic forests in southern Finland. Forest Ecology and Management, 128(3), 211-225. DOI: 10.1016/S0378-1127(99)00148-6.

18. Sjors, H. (1963). Amphi-Atlantic zonation. Nemoral to arctic. North Atlantic Biota and their History, 1098-1125.

19. Stokland, J.N. (2001). The coarse woody debris profile: an archive of recent forest history and an important biodiversity indicator. Ecological Bulletins, 71-83.

20. Stokland, J.N., Siitonen, J., \& Jonsson, B.G. (2012). Biodiversity in dead wood: Cambridge University Press. DOI: 10.1017/CBO9781139025843.

21. Timonen, J., Gustafsson, L., Kotiaho, J.S., \& Mönkkönen, M. (2011). Hotspots in cold climate: conservation value of woodland key habitats in boreal forests. Biological Conservation, 144(8), 2061-2067. DOI: 10.1016/j.biocon.2011.02.016.

22. Timonen, J., Siitonen, J., Gustafsson, L., Kotiaho, J.S., Stokland, J.N., Sverdrup-Thygeson, A., \& Mönkkönen, M. (2010). Woodland key habitats in northern Europe: concepts, inventory and protection. Scandinavian Journal of Forest Research, 25(4), pp. 309-324. DOI: 10.1080/02827581.2010.497160. 